\title{
Studies on Aerobiology and Epidemiology of Late Blight Disease of Potato
}

\author{
H. N. Supriya ${ }^{1 *}$, M. S. Nagaraj ${ }^{1}$ and G. K. Sudarshan ${ }^{2}$ \\ ${ }^{1}$ University of Agricultural Sciences, Bengaluru, Karnataka-560065, India \\ ${ }^{2}$ University of Horticultural Sciences, Bagalkot, Karnataka- 587104, India \\ *Corresponding author
}

\section{A B S T R A C T}

\begin{tabular}{|l|}
\hline K e y w o r d s \\
Late blight, \\
$\begin{array}{l}\text { Phytophthora } \\
\text { infestans, } \\
\text { Aerobiology }\end{array}$ \\
\hline Article Info \\
\hline $\begin{array}{l}\text { Accepted: } \\
\text { 20 September } 2020 \\
\text { Available Online: } \\
\text { 10 October } 2020\end{array}$ \\
\hline
\end{tabular}

Late blight caused by Phytophthora infestans (Mont.) de Bary has been recorded as one of the devastating disease and is considered as one of the limiting biotic factor for potato cultivation. The study pertaining to Aerobiology of Phytophthora infestans revealed that the aerial concentration of sporangia decreased progressively with height above the pant canopy, the highest concentration of spores was registered during Kharif (0-59.93/week) compare to Rabi (0-30.79/week). Rainfall, relative humidity and minimum temperature showed positive correlation while maximum temperature and evapotranspiration had negative correlation with spore load. Under field conditions, disease was affected by variation in weather variables, as cool temperature $\left(16-23^{\circ} \mathrm{C}\right)$ and wet weather coincides with high relative humidity $(>90 \%)$ and rainfall of $1.5-4.2 \mathrm{~mm}$ favored the disease progression.

\section{Introduction}

Potato (Solanum tuberosum L.) is the world's largest grown vegetable crop followed by sweet potato and tomato and ranks fourth in the worldwide production after maize, rice and wheat. In India, the potato covers an area of 21.79 lakh ha with yearly production of $53,027.21$ tonnes. Karnataka stands $11^{\text {th }}$ among potato producing states in India, which accounts for 1.23 per cent of overall potato production (Annon, 2019).

In Karnataka potato has been grown in four Agro-climatic zones viz., Southern transitional (Hassan and Chikmagalur), Hilly zone (Chikmagalur), Northern transitional Zone (Belagavi and Dharwad) and Eastern dry zone (Kolar, Chikkaballapur and Bangalore Rural). It is mainly grown as Kharif crop in Dharwad, Belagavi, Hassan and Chikmagalur districts, whereas, it's grown as Rabi crop in Bangalore and Kolar district. The Rabi crop is irrigated, whereas the kharif is totally rainfed. Potatoes produced in Kharif contributes largest portion (70\%) of potatoes produced in Karnataka. Hassan district stands first in area followed by Belagavi and Kolar district.

Since the active period of crop coincides with the monsoon rains followed by cool 
temperature, favours the development of various fungal and bacterial diseases. Poor agricultural practices can also lead to increase in disease incidences, reduction in yield and also quality of the produce.

Among the diseases, late blight of potato caused by Phytophthora infestans (Mont.) de Bary is the most destructive disease affecting leaves, stem, petioles and tuber. It has been documented that under unfavourable environmental conditions, late blight can cause considerable yield losses and can lead up to 100 per cent yield losses.

However, the onset of infection and the severity vary considerably from year to year as the disease epidemic depends on weatherparameters and aerial spore quantity which accounts for the spread of disease. Sporangia of $P$. infestans are thought to be dispersed by wind. Monitoring the pathogen's airborne inoculum along with the weather parameter could therefore help to forecast blight epidemic and need for fungicidal sprays.

Hence, scheduling timely application of fungicides based on the spore concentrations in plant canopy by obtaining reliable predictive models that allow us to know beforehand the atmosphere spore content in a particular area and the suitable meteorological conditions for occurrence of aerial sporangia, can lead to forecasting the emergence of fungal blight. These allows the utilization of forecasting tools for deliberating the need based and timely application of fungicides and to reduce the cost of cultivation.

\section{Materials and Methods}

Field experiment was carried out in both Kharif and Rabi, 2019 season at Agricultural Research Station. Gunjevu, Hassan is located in the Southern transition zone (Zone-7) of Karnataka state at $12.874^{\circ} \mathrm{N}$ latitude, $76.379^{\circ}$
E longitude with an altitude of $874 \mathrm{~m}$ above the mean sea level. Seed tubers of cultivar Kufri Jyothi were sown into the field with $60 \mathrm{~cm}$ inter $20 \mathrm{~cm}$ intra row spacing in plots measuring $25 \times 20 \mathrm{~m}$. All the agronomical practices and pest control measures were followed as per the recommended package of practices.

Aerobiological studies were carried out to trap the sporangia present in the air current during 2019. For this, aeroscope exposure of stationary slide was done by mounting it on a wind vane and placed inside potato field at two different heights (at plant canopy and 1mt above ground level) (Plate1).

A slide, which was thinly smeared with vaseline was used for trapping spores, by keeping smeared slide in the slot inside the box. The slide was removed every day at 8.00am. Average number of sporangia per microscopic field was recorded under low power objective taking count of ten microscopic fields on a slide (Plate 2).

Further, to understand the influence of environmental factors on aerial spore load and development of the disease the weather parameters viz., temperature, relative humidity, evapo- transpiration and rain fall data were recorded during cropping period and they were correlated with spore load and disease development by simple correlation and multiple regression analysis (Table 1 and $2)$. Ten plants were randomly selected and tagged for regular observations. Observation on disease severity of foliage was recorded by using 1-9 scale as given by CIP and per cent disease index (PDI) was worked out using formula of wheeler1969. The fruit yield in each plot was also recorded.

CIP scale for recording the field observation on potato late blight: 


\begin{tabular}{|c|c|}
\hline \% area infected & Scale \\
\hline 0 & 1 \\
\hline Up to 3 & 2 \\
\hline Up to 10 & 3 \\
\hline Up to 25 & 4 \\
\hline Up to 50 & 5 \\
\hline Up to 75 & 6 \\
\hline Up to 90 & 7 \\
\hline Up to 99 & 8 \\
\hline Up to 100 & 9 \\
\hline
\end{tabular}

\section{Results and Discussion}

Studies on aerobiology of Phytophthora infestans revealed that the sporangia were trapped throughout the crop season, initially sporangia was trapped on $11^{\text {th }}$ July (Kharif),

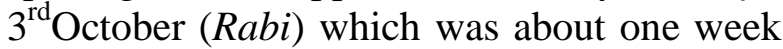
before first disease symptoms appeared (July $18^{\text {th }}$ Kharif, October $11^{\text {th }}$ Rabi) noticed that onset of infection begun one week after the appearance of first aerial spore of $P$. infestans.

\section{Concentration profiles}

The aerial concentration of sporangia decreased rapidly with height above the canopy (Fig. 1 and 2). Spore concentrations measured by the sampler just above the top of the canopy ranged from 3.26 to 48.84 sporangia/week in Kharif and from1.5 to 21.56 sporangia /week in Rabi.

Similarly, Spore concentrations measured by the sampler at $1 \mathrm{~m}$ above the ground level ranged from 3.24 to 22.36 sporangia/week in Kharif and from 1.52 to 9.23 sporangia /week in Rabi. These findings are in agree with Aylor et al., (2001)who conducted an experiment to determine the rate of release of sporangial spores per square meter per second for quantifying their further dispersal and the potential spread of disease. Values of $\mathrm{Q}$ (spores) were obtained for Phytophthora infestans sporangia released from an area source of diseased plants in a potato canopy recorded highest when compared with the concentrations of airborne sporangia measured at several heights above the source.

Simple correlation and multiple linear regressions with spore load of Phytophthora infestans in relation to weather parameters

The relationship was established between weather parameters viz., maximum and minimum temperature, relative humidity, rainfall and evapotranspiration with spore load of Phytophthora infestans through correlation and multiple linear regression analysis. The correlation coefficients are presented in Table 3.

The relationship between spore load of $P$. infestans and weather factors during both season in 2019 indicated that minimum temperature, relative humidity and rainfall was positively correlated with weekly spore load. Whereas maximum temperature and evapotranspiration was negatively correlated. The data are again subjected to multiple linear regression analysis.

The coefficient of multiple correlation $\left(\mathrm{R}^{2}\right)$ was calculated to measure the contribution of linear function of independent variables such as maximum temperature $\left(\mathrm{X}_{1}\right)$, minimum temperature $\left(\mathrm{X}_{2}\right)$, relative humidity $\left(\mathrm{X}_{3}\right)$, rainfall $\left(\mathrm{X}_{4}\right)$ and evapotranspiration $\left(\mathrm{X}_{5}\right)$ on dependent variable i.e. average spore load (Y) and is presented in the Table 4.

The multiple regression equation was found highly significant for the data with the spore load, revealed that spore load recorded in microclimate of potato field was governed up to 86.80 per cent in Kharif and 83.30 per cent in $R a b i$ by the cumulative effects of independent environmental factors (relative humidity, maximum temperature, minimum temperature, rainfall and evapotranspiration). 
Table.1 Effect of different meteorological factors on spore load of Phytophthora infestans and disease progression during Kharif-2019 at Agriculture Research Station, Gunjevu

\begin{tabular}{|c|c|c|c|c|c|c|c|c|c|c|}
\hline \multirow{2}{*}{$\begin{array}{l}\text { Standard } \\
\text { week No }\end{array}$} & \multirow{2}{*}{$\begin{array}{l}\text { Month and } \\
\text { Date }\end{array}$} & \multicolumn{3}{|c|}{ Average spore load } & \multirow{2}{*}{$\begin{array}{c}\text { Disease } \\
\text { severity } \\
(\%)\end{array}$} & \multicolumn{2}{|c|}{ Temperature $\left({ }^{\circ} \mathrm{C}\right)$} & \multirow[t]{2}{*}{ RH (\%) } & \multirow[t]{2}{*}{$\mathbf{R F}(\mathbf{m m})$} & \multirow[t]{2}{*}{ ET (mm/day) } \\
\hline & & $\begin{array}{l}\text { At plant } \\
\text { canopy }\end{array}$ & $\begin{array}{l}\text { 1mt above } \\
\text { ground level }\end{array}$ & $\begin{array}{c}\text { Total spore } \\
\text { load }\end{array}$ & & Max. & Min. & & & \\
\hline 28 & July 01-08 & 0.00 & 0.00 & 0.00 & 0.00 & 24.18 & 16.06 & 85.87 & 2.92 & 4.00 \\
\hline 29 & July 09-16 & 3.26 & 0.00 & 3.26 & 0.00 & 24.26 & 16.00 & 88.62 & 0.57 & 4.00 \\
\hline 30 & July17-24 & 6.00 & 0.00 & 6.00 & 3.54 & 24.25 & 16.00 & 86.12 & 0.70 & 4.00 \\
\hline 31 & July $25-31$ & 08.32 & 03.24 & 11.56 & 9.20 & 24.14 & 15.79 & 85.00 & 0.60 & 4.00 \\
\hline 32 & Aug 01-08 & 17.60 & 10.83 & 28.43 & 18.00 & 23.00 & 15.43 & 91.25 & 10.27 & 2.50 \\
\hline 33 & Aug 09-16 & 21.03 & 09.56 & 30.56 & 30.50 & 23.31 & 16.18 & 94.87 & 16.02 & 1.25 \\
\hline 34 & Aug 17-24 & 39.00 & 15.20 & 54.2 & 42.50 & 23.62 & 16.81 & 91.00 & 3.97 & 1.87 \\
\hline 35 & Aug 25-31 & 35.30 & 18.34 & 53.64 & 57.62 & 23.20 & 17.10 & 92.40 & 1.00 & 2.00 \\
\hline 36 & Sep 01-08 & 42.60 & 14.92 & 57.52 & 69.00 & 22.00 & 16.62 & 94.50 & 1.90 & 2.00 \\
\hline 37 & Sep 09-16 & 37.52 & 22.36 & 59.88 & 78.42 & 24.18 & 16.93 & 94.87 & 1.25 & 2.00 \\
\hline 38 & Sep 17-24 & 48.84 & 23.00 & 71.84 & 83.64 & 24.12 & 17.00 & 94.50 & 9.40 & 2.62 \\
\hline 39 & Sep 25-30 & 40.41 & 19.52 & 59.93 & 93.80 & 24.25 & 17.00 & 94.16 & 11.96 & 3.00 \\
\hline
\end{tabular}

Table.2 Effect of different meteorological factors on spore load of Phytophthora infestans and disease progression during Rabi-2019 at Agriculture Research Station, Gunjevu

\begin{tabular}{|c|c|c|c|c|c|c|c|c|c|c|}
\hline \multirow{2}{*}{$\begin{array}{l}\text { Standard } \\
\text { week No }\end{array}$} & \multirow{2}{*}{$\begin{array}{c}\text { Month and } \\
\text { Date }\end{array}$} & \multicolumn{3}{|c|}{ Average spore load } & \multirow{2}{*}{$\begin{array}{c}\text { Disease } \\
\text { severity } \\
(\%)\end{array}$} & \multicolumn{2}{|c|}{ Temperature $\left({ }^{\circ} \mathrm{C}\right)$} & \multirow[t]{2}{*}{ RH (\%) } & \multirow{2}{*}{$\begin{array}{l}\text { RF } \\
(\mathbf{m m})\end{array}$} & \multirow{2}{*}{$\begin{array}{c}\text { ET } \\
(\mathbf{m m} / \text { day })\end{array}$} \\
\hline & & $\begin{array}{l}\text { At plant } \\
\text { canopy }\end{array}$ & $\begin{array}{l}\text { 1mt above } \\
\text { ground level }\end{array}$ & $\begin{array}{c}\text { Total spore } \\
\text { load }\end{array}$ & & Max. & Min. & & & \\
\hline 40 & Oct $01-08$ & 1.56 & 0.00 & 1.56 & 0.00 & 25.18 & 14.56 & 92.25 & 6.10 & 4.00 \\
\hline 41 & Oct $09-16$ & 2.00 & 0.00 & 2.00 & 18.26 & 24.93 & 14.43 & 90.62 & 3.60 & 4.00 \\
\hline 42 & Oct $17-24$ & 16.23 & 5.19 & 21.42 & 19.60 & 22.87 & 14.25 & 95.50 & 4.90 & 4.00 \\
\hline 43 & Oct $25-31$ & 21.56 & 9.23 & 30.79 & 22.30 & 23.57 & 14.00 & 92.14 & 3.54 & 2.78 \\
\hline 44 & Nov 01-08 & 12.60 & 6.25 & 18.85 & 25.14 & 26.75 & 14.00 & 92.00 & 0.00 & 4.00 \\
\hline 45 & Nov $09-16$ & 7.62 & 3.21 & 10.83 & 26.14 & 25.31 & 14.52 & 94.56 & 0.00 & 4.00 \\
\hline 46 & Nov17-24 & 7.30 & 1.52 & 8.83 & 29.45 & 25.15 & 15.00 & 95.20 & 0.00 & 4.00 \\
\hline 47 & Nov $25-30$ & 5.68 & 2.15 & 7.83 & 31.00 & 24.51 & 14.50 & 91.00 & 0.00 & 4.00 \\
\hline 48 & Dec 01-08 & 4.21 & 1.15 & 5.36 & 33.48 & 24.86 & 14.62 & 92.00 & 0.00 & 3.10 \\
\hline 49 & Dec 09-16 & 2.56 & 0.72 & 3.28 & 34.00 & 23.75 & 15.20 & 93.50 & 0.00 & 3.62 \\
\hline 50 & Dec 17-24 & 3.56 & 0.15 & 3.71 & 34.12 & 26.53 & 14.20 & 92.41 & 0.00 & 4.00 \\
\hline 51 & Dec 25-31 & 3.00 & 0.38 & 3.38 & 34.58 & 26.15 & 14.52 & 92.57 & 0.00 & 4.00 \\
\hline
\end{tabular}


Table.3 Correlation of spore load of late blight of potato with meteorological factors under field condition during Kharif and Rabi-2019

\begin{tabular}{|l|c|c|}
\hline \multirow{2}{*}{ Correlation pairs } & \multicolumn{2}{c|}{ Correlation coefficient } \\
\cline { 2 - 3 } & Kharif-2019 & Rabi-2019 \\
\hline Spore load× Maximum temperature (X1) & -0.307 & -0.390 \\
\hline Spore load× Minimum temperature (X2) & $0.826 * *$ & $0.598^{*}$ \\
\hline Spore load× Relative humidity (X3) & $0.850^{* *}$ & 0.238 \\
\hline Spore load× Rainfall(X4) & 0.281 & 0.223 \\
\hline Spore load× Evapotranspiration(X5) & $-0.714 * *$ & -0.450 \\
\hline
\end{tabular}

**Significant at $1 \%$ probability(Two-tailed) $*$ Significant at $1 \%$ probability(Two-tailed)

Table.4 Cumulative influence of weather parameter depicting estimates of spore load of late

blight through multiple correlation and regression analysis during Kharif and Rabi-2019

\begin{tabular}{|c|c|c|}
\hline Crop season & $\begin{array}{c}\text { Multiple } \\
\text { correlation } \\
\text { coefficient }\left(\mathbf{R}^{2}\right)\end{array}$ & Regression equation \\
\hline Kharif-2019 & 0.868 & $\mathrm{Y}=-547.34-4.33 \mathrm{X}_{1}+25.416 \mathrm{X}_{2}+2.951 \mathrm{X}_{3}+0.171 \mathrm{X}_{4}-0.102 \mathrm{X}_{5}$ \\
\hline Rabi-2019 & 0.833 & $\mathrm{Y}=190.50-3.159 \mathrm{X}_{1}+21.388 \mathrm{X}_{2}+2.497 \mathrm{X}_{3}-0.821 \mathrm{X}_{4}-5.969 \mathrm{X}_{5}$ \\
\hline
\end{tabular}

Table.5 Correlation of percent disease severity of late blight of potato with meteorological factors under field condition during Kharif and Rabi-2019

\begin{tabular}{|l|c|c|}
\hline \multirow{2}{*}{ Correlation pairs } & \multicolumn{2}{|c|}{ Correlation coefficient } \\
\cline { 2 - 3 } & Kharif-2019 & Rabi-2019 \\
\hline Spore load× Maximum temperature (X1) & -0.176 & -0.174 \\
\hline Spore load× Minimum temperature (X2) & $0.850^{* *}$ & 0.223 \\
\hline Spore load× Relative humidity (X3) & $0.834^{* *}$ & 0.064 \\
\hline Spore load× Rainfall(X4) & 0.284 & $0.886^{* *}$ \\
\hline Spore load× Evapotranspiration(X5) & $-0.578^{*}$ & -0.132 \\
\hline
\end{tabular}

**Significant at $1 \%$ probability(Two-tailed) $*$ Significant at $1 \%$ probability(Two-tailed)

Table.6 Cumulative influence of weather parameter depicting estimates of percent disease severity of late blight through multiple correlation and regression analysis during Kharif and

Rabi-2019

\begin{tabular}{|l|c|c|}
\hline Crop season & $\begin{array}{l}\text { Multiple correlation } \\
\text { coefficient }\left(\mathbf{R}^{2}\right)\end{array}$ & Regression equation \\
\hline Kharif-2019 & 0.903 & $\mathrm{Y}=-1072.87-5.318 \mathrm{X}_{1}+36.435 \mathrm{X}_{2}+6.591 \mathrm{X}_{3}+0.458 \mathrm{X}_{4}+13.997 \mathrm{X}_{5}$ \\
\hline Rabi-2019 & 0.877 & $\mathrm{Y}=177.806-2.963 \mathrm{X}_{1}-4.036 \mathrm{X}_{2}-0.0225 \mathrm{X}_{3}-4.674 \mathrm{X}_{4}-0.573 \mathrm{X}_{5}$ \\
\hline
\end{tabular}


Fig.1 Graphical representation of Average spore load of Phytophthora infestans recorded duringKharif-2019

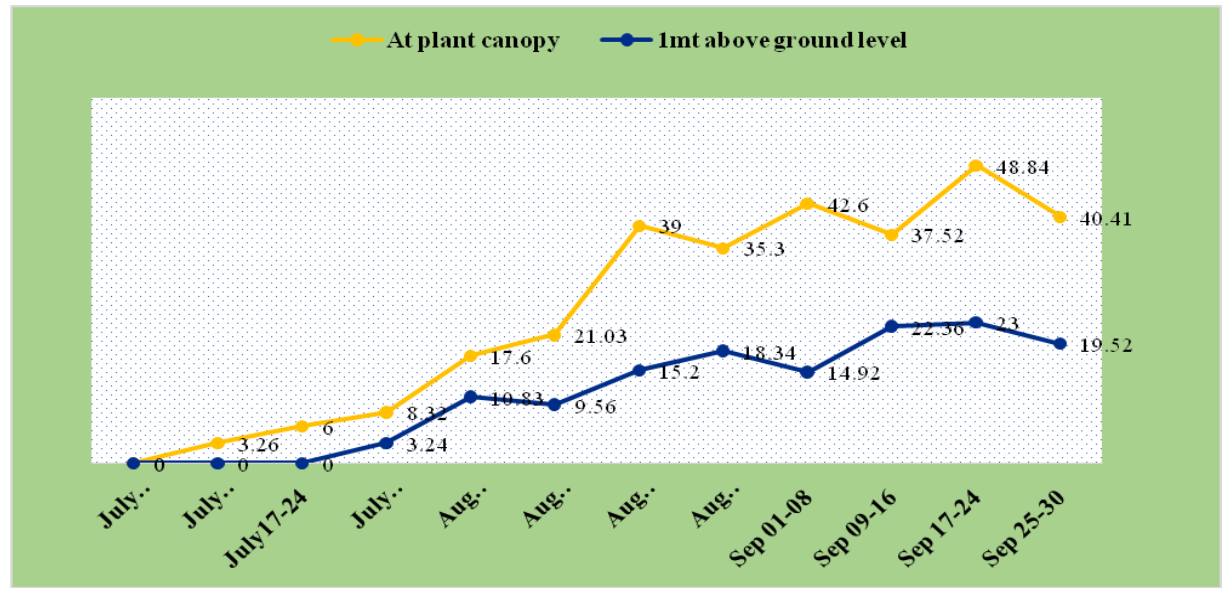

Fig.2 Graphical representation of Average spore load of Phytophthora infestans recorded during Rabi-2019

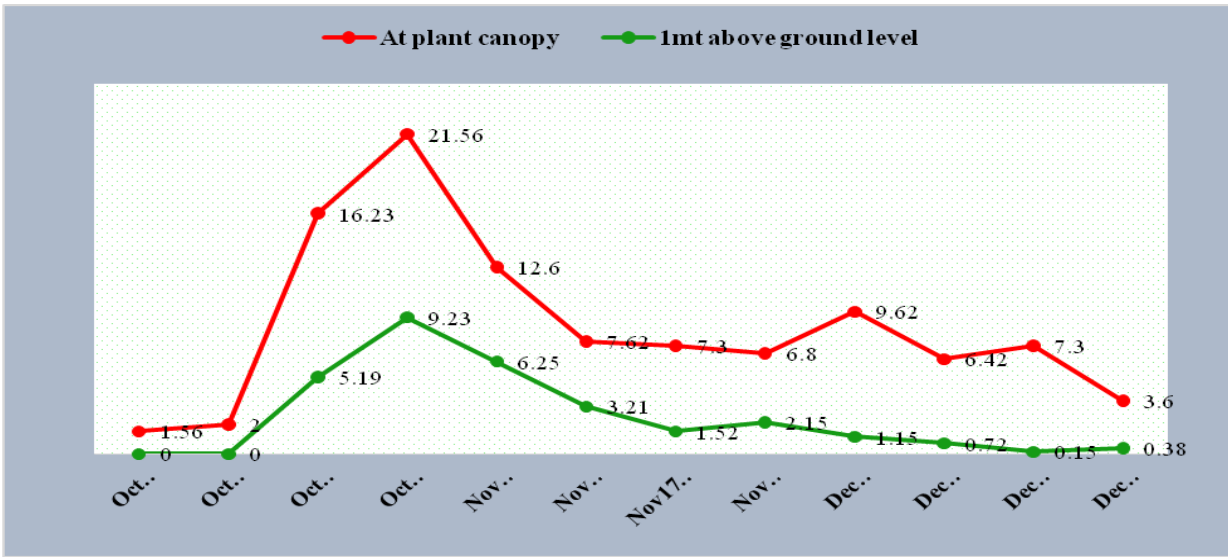

Plate.1 View of Spore trap installed in potato field at plant canopy and at one meter above ground level to quantify spore number
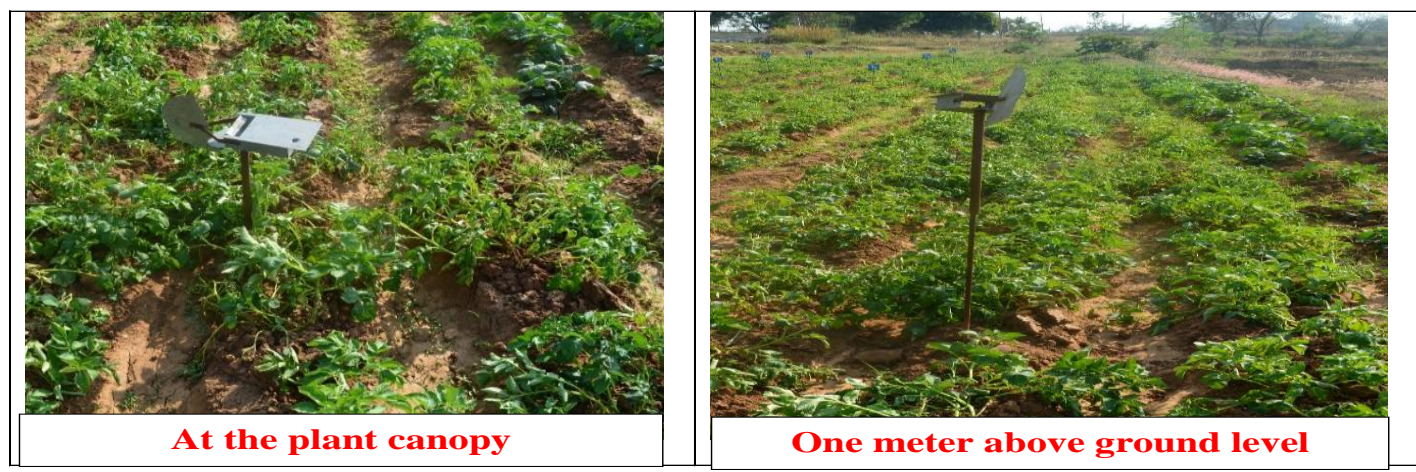
Plate.2 Microscopic view of sporangia obtained from spore trap installed in Potato field
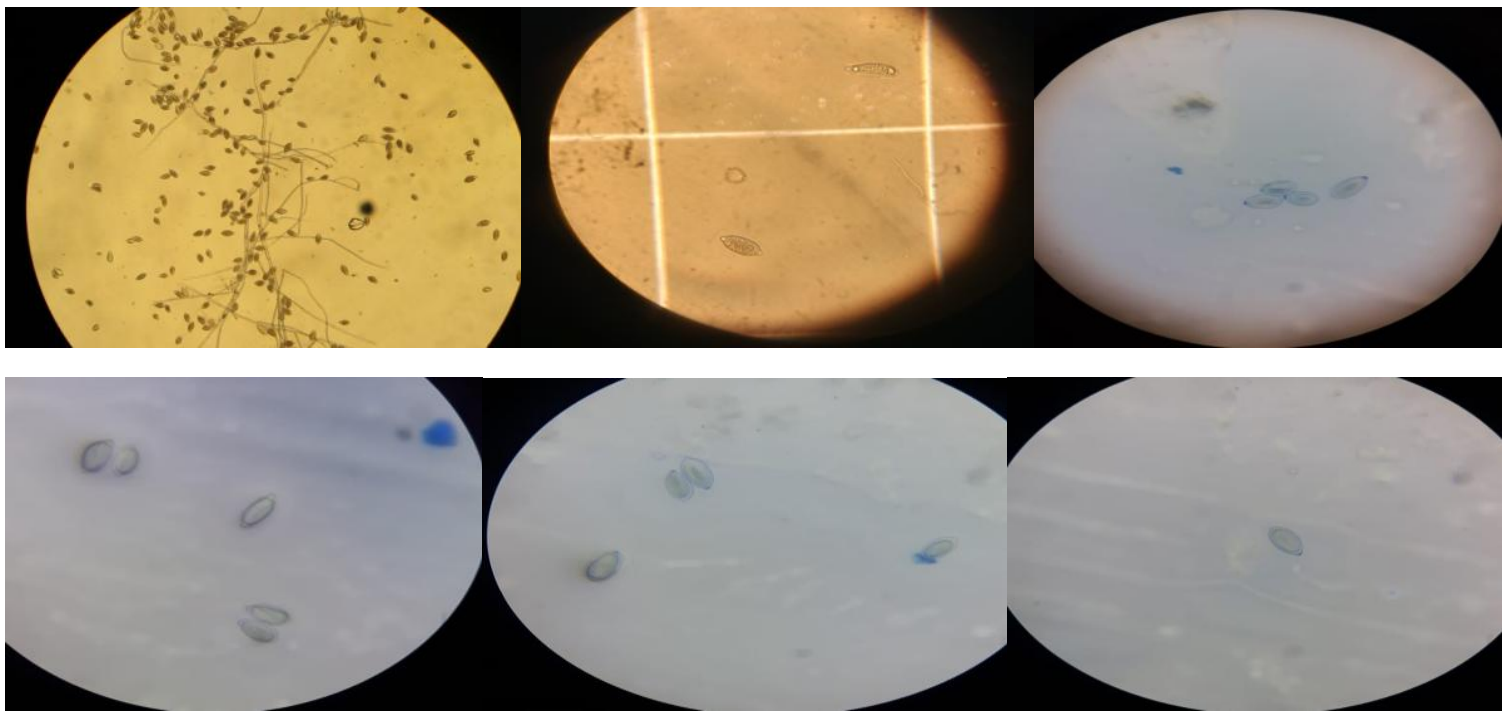

These findings are in line with Roopa (2012) who conducted aerobiology study on early blight of tomato. She developed the relationship between spore load of $A$. solani and weather factors during 2011 indicated that maximum temperature and rainfall found significantly positively correlated with spore load, whereas minimum temperature, morning relative humidity and evening relative humidity were significantly negatively correlated with weekly spore load, multiple linear regression equation was developed for 2011 was $\mathrm{Y}=-17.116$ $+0.092 \mathrm{X}_{1}-0.333 \mathrm{X}_{2}+1.211 \mathrm{X}_{3}-1.485$ $\mathrm{X}_{4}+0.363 \mathrm{X}_{5}$ With $\mathrm{R}^{2}=0.86$ i.e., the weather factors put together influence spore load to the extent of 86 per cent.

Simple correlation and multiple linear regression with percent disease severity of Phytophthora infestans in relation to weather parameters

The perusal of simple correlation studied (Table 5) revealed that the metrological parameters including minimum temperature, relative humidity and rainfall were positively correlated with percent disease severity of
Phytophthora infestans indicating simultaneous increase in the disease development with increase in minimum temperature, $\mathrm{RH}$ and rainfall during both season of 2019. Whereas maximum temperature and evapotranspiration was found to be negatively correlated indicating that late blight severity decreased gradually with increase of maximum temperature. These findings are in agree with Koushal (2019)who reported the positive correlation of tomato late blight with minimum temperature, relative humidity, mean air temperature and rainfall, negative correlation with maximum temperature.

The coefficient of multiple correlation $\left(\mathrm{R}^{2}\right)$ was calculated to measure the contribution of linear function of independent variables such as maximum temperature $\left(\mathrm{X}_{1}\right)$, minimum temperature $\left(\mathrm{X}_{2}\right)$, relative humidity $\left(\mathrm{X}_{3}\right)$, rainfall $\left(\mathrm{X}_{4}\right)$ and evapotranspiration $\left(\mathrm{X}_{5}\right)$ on dependent variable i.e. percent disease severity (Y).

The multiple regression equation was found highly significant for the data with the spore load, revealed that progression of late blight 
disease was governed up to 90.30 per cent in Kharif and 87.70per cent in Rabi by the cumulative effects of independent environmental factors (relative humidity, maximum temperature, minimum temperature, rainfall and evapotranspiration). The significance of the coefficients is presented in Table 6 .

Thus, the study revealed that there will be a significant increase of late blight severity and spore load concentration when the maximum temperature less than $24^{\circ} \mathrm{C}$, relative humidity more than 90 Per cent, minimum temperature from $12-16^{\circ} \mathrm{C}$ and rainfall ranged from 1.5 $4.2 \mathrm{~mm}$. The findings are in agreement with the studies of Iglesias et al., (2009) reported the studies on seasonal variation of Phytophthora infestans concentrations in atmosphere and the highest concentrations of spores were registered during June and July from 82-145 spores $/ \mathrm{m}^{3}$ as a result of the maximum temperature around $16-23^{\circ} \mathrm{C}$. Ahmed et al., (2015) studied the effect various environmental factors on late blight severity and they found that high relative humidity of 63-71 Per cent coupled with rainfall ranged from $1.5-3.75 \mathrm{~mm}$, temperature range from $16-20^{\circ} \mathrm{C}$ and wind speed in the range of $1-$ $5.5 \mathrm{Km} / \mathrm{h}$ were significantly favoured the disease development.

\section{References}

Ahmed, N., Aslam, M. and Alia, M. A., 2015. Prediction of potato late blight disease based upon environmental factors in Faisalabad, Pakistan. JPPM., 4:1-4.

Anonymous,2019.State department of Horticulture and Agriculture, GOI. www.potatopro.com.

Aylor, D. E., Fry, W. E., Mayton, H. and Andrade-piedra, J. L., 2001. Quantifying the rate of release and escape of Phytophthora infestans sporangia from a potato canopy.
Phytopathol., 91:1189-1196.

Beaumont, A., 2006. The dependence on the weather of the dates of outbreak of potato blight epidemics. Trans. Brit. Mycol. Soc., 31:45-53.

Das, S. and Gupta-Bhattacharya, S., 2012. Monitoring and assessment of airborne fungi in Kolkata, India, by viable and non-viable air sampling methods. Environ. Monit. Assess., 184(8): 4671-4684.

Dedeurwaeder, G., Duvivier, M., Mvuyerkure, S. M., Renard, M, E., Vanhese, V., Marchal, G. andLegreve, A., 2011. Spore traps network: a new tool for predicting epidemics of wheat yellow rust. Commun. Agric. Appl. Biol. Sci., 76: 667-670.

Fahim, M. A., Hassanien, M. K. and Mostafa, M. H., 2003. Relationships between climatic conditions and Potato Late Blight epidemic in Egypt during winter seasons 1999-2001. Appl. Ecol. Environ. Res., 1(1-2):159-172.

Harrison, J. G., 1995. Factors involved in the development of potato late blight disease (Phytophthora infestans). Potato ecology and modelling of crops under conditions limiting growth. pp. 215-216.

Iglesias, I., Escuredo, O., Seijo, C. and Mendez, J., 2010.Phytophthora infestans prediction for a potato crop. Am.J. Potato Res., 87(1): 32-40.

Johnson, D. A., Alldredge, J. R., Hamm, P. B.and Frazier, B. E., 2003. Aerial photography used for spatial pattern analysis of late blight infection in irrigated potato circles. Phytopathology, 93(7): 805-812.

Kessel, G. J. T., Holtslag, A. A. M., Moene, A. F. and Van der werf, W., 2009. Regional spore dispersal as a factor in disease risk warnings for potato late blight: a proof of concept. Agr.Forest meteorol., 149(3-4): 419-430. 
Koushal, S., 2019, Epidemiology and management of late blight of tomato. Ph.D thesis. Dr. Yashwant Singh Parmar University of Horticulture and Forestry, Solan.

Lima, M. A., Maffia, L. A., Barreto, R. W. and Mizubuti, E. S. G., 2009.Phytophthora infestans in a subtropical region: survival on tomato debris, temporal dynamics of airborne sporangia and alternative hosts. Plant Pathology, 58(1): 87-99.

Meredith, D. S.,1973. Significance of spore release and dispersal mechanisms in plant disease epidemiology. Annu. Rev. Phytopathol., 11(1): 313-342.

Roopa, R. S., 2012. Epidemiology and management of early blight of tomato caused by Alternaria solani (Ellis and
Martin) Jones and Grout. M.Sc. (Agri) thesis, University of Agricultural Science, Dharwad.

Sharma, P. and Saikia, M. K., 2013. Management of late blight of potato through chemicals. J. Agric. Vet. Sci., 2: 23-36.

Thakur, M. P. and Khare, M. N., 1991. Epidemiology and aerobiology of Mungbean anthracnose. Indian $J$. Mycol. Plant Path., 21(3): 233-240.

Tiwari., Pratima. and Singh, B, K., 2019. Climate based factor analysis and epidemiology prediction for potato late blight using machine learning approaches. Ph.D. Thesis, G.B. Pant University of Agriculture and Technology, Pantnagar.

\section{How to cite this article:}

Supriya, H. N., M. S. Nagaraj and Sudarshan, G. K. 2020. Studies on Aerobiology and Epidemiology of Late Blight Disease of Potato. Int.J.Curr.Microbiol.App.Sci. 9(10): 25922600. doi: https://doi.org/10.20546/ijcmas.2020.910.312 